\title{
Article
}

\section{The 8.2 ka BP Holocene climate change event and human population resilience in northwest Atlantic Europe}

Griffiths, Seren and Robinson, Erick

Available at http://clok.uclan.ac.uk/20621/

Griffiths, Seren ORCID: 0000-0001-5168-9897 and Robinson, Erick (2018) The $8.2 \mathrm{ka}$ BP Holocene climate change event and human population resilience in northwest Atlantic Europe. Quaternary International, 465 (B). pp. 251-257. ISSN 1040-6182

It is advisable to refer to the publisher's version if you intend to cite from the work. http://dx.doi.org/10.1016/j.quaint.2017.10.017

For more information about UCLan's research in this area go to http://www.uclan.ac.uk/researchgroups/ and search for <name of research Group>.

For information about Research generally at UCLan please go to http://www.uclan.ac.uk/research/

All outputs in CLoK are protected by Intellectual Property Rights law, including Copyright law. Copyright, IPR and Moral Rights for the works on this site are retained by the individual authors and/or other copyright owners. Terms and conditions for use of this material are defined in the policies page.

\section{CLoK}

Central Lancashire online Knowledge www.clok.uclan.ac.uk

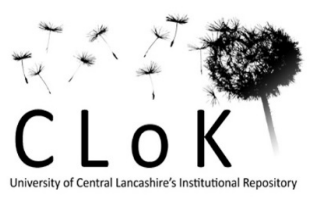




\title{
The 8.2 ka BP Holocene climate change event and human population resilience in northwest Atlantic Europe
}

\author{
Seren Griffiths ${ }^{1}$ and Erick Robinson ${ }^{2}$ \\ ${ }^{1}$ Archaeology, School of Forensics and Applied Science, University of Central \\ Lancashire, Preston, PR1 2HE, UK \\ ${ }^{2}$ Department of Anthropology, University of Wyoming, Laramie, 1000 East University \\ Avenue, WY, 82071, USA
}

\section{Abstract}

The 8.2 ka BP event may represent the largest, most abrupt Holocene climate event. This paper examines the impact of this event on human activity in the middle Mesolithic. It produces Bayesian statistical models for the chronology of anthropogenic sites in northwest Atlantic Europe for a 1000 year time window around the event to explore evidence for human responses to climate change or resilience in the face of this climate change event. By approaching evidence for activity at sites in Denmark, Belgium, France, Ireland and Britain we explore evidence for differential temporally- and spatially-transgressive local responses to climate change in this period to move to sub-continental scales of activity.

\section{Introduction}

Research on the impact of abrupt climate changes on Mesolithic societies promises to enhance our knowledge of the complexity and diversity of humanenvironment interactions during the early and middle Holocene across Europe. This knowledge will be gained by first asking if there is evidence for an impact on Mesolithic societies, then moving on to how these societies adapted to them. The latter focuses on what specific strategies were used to enhance adaptation and resilience to palaeoclimate events, such as changes in social organization, land use, subsistence, and technology.

There are two levels of analysis that must be carried out to achieve these aims. The first level of analysis collects all archaeological and palaeoenvironmental data from the particular region of interest and assesses whether it has the appropriate chronological resolution required to investigate potential impacts on human populations of abrupt climate events. At this level of analysis, one assessment that can be made of climate change is whether there is evidence for declines in human populations in the region of focus, or whether populations appeared to be resilient to climate change. This first level of analysis is essential for moving on to the second level of analysis that investigates the specific adaptive strategies that made Mesolithic societies resilient to abrupt climate changes.

Over the past decade an increasing amount of research has been carried out on the impacts of the ' $8.2 \mathrm{ka}$ BP event' (Alley et al.1997) on Mesolithic societies throughout Europe. In northwest Europe, hypotheses for the impact of this event have ranged from population crashes (Riede 2009; Wicks and Mithen 2014) to changes in social and/or technological organization (Riede 2009; Robinson et al. 2013; Manninen 2014). These analyses have relied on an approach that sums the probability distributions of individual calibrated radiocarbon dates and qualitatively matches the time-series wiggles in these distributions to different palaeoclimate and palaeoenvironmental records. Many of these approaches have employed the sums of calibrated radiocarbon dates (summed probability distributions: SPDs).

In this paper we propose another method to start to investigate the responses of Mesolithic populations to the $8.2 \mathrm{ka}$ BP event. We argue that, while SPDs can provide important hypothesis development (e.g. Shennan et al. 2013), due to the 
continued uncertainty about the relative timing of regional ecosystem responses to the 8.2 ka BP event (Magny et al. 2003; Seppä et al. 2007; Prasad et al. 2009; Zillén and Snowball 2009; Giesecke et al. 2011; Torbenson et al. 2015), as well as its possible occurrence within a longer period of climate change (Röling and Palicke 2005), we must move beyond initial SPDs to a more Bayesian approach that selects sites within a region that fall within a wider 'envelope' before, during, and after the event. Moreover, recent treatments of radiocarbon dates as proxies for human population levels have adopted a chronology which interrogates data at the precision of 200 year bins (e.g. Crema et al. 2016). This method is adopted to down weight regions where lots of research has occurred and therefore there are more radiocarbon data as a result, not of past population, but contemporary archaeological research strategies. In terms of our investigation this kind of SPD approach has two limitations. We regard the 200 year precision as too coarse to identify individuals' responses the shortlife events. Two hundred years is significantly beyond the duration of individuals' lives or generations, and we argue is therefore not sufficient to see human responses at the level of individual sites. Equally importantly, while the SPD method downweights the effects of contemporary archaeological research bias what it cannot do is account for variation in human activity in the past; if more radiocarbon data exist across a region because different types of activity produce different higher levels of archaeological visibility SPDs would reflect differences in ancient cultural choices not ancient population levels.

Our method has several distinct benefits. First, it determines what data are available for human populations for a particular region. Second, it determines whether or not there is a persistence of occupation at these individual sites. Third, it delineates which sites - that were likely excavated and analyzed with different questions in mind - need to be returned to for further study into specific Mesolithic groups' responses to this period of climatic change. This could include further work in terms of further excavation to obtain higher resolution data, on-site environmental data, and so on, or returning site archives to reinvestigate subsistence data, material culture, or collect new samples for dating. Fourth, this approach allows us to investigate any spatial patterning in response to the $8.2 \mathrm{ka}$ BP event which might derive from specific environmental conditions or ecosystem responses in different parts of the study area. Fifth, this approach, when expanded to the palaeoenvironmental sequences, will determine whether or not the high chronological resolution palaeoenvironmental records required for sub centennial climate events currently exist for a given region. This approach of using occupation at individual sites, at the continental-scale, in the period pre- and post- a climatic event, has never been attempted before. We suggest this is an important step in looking at the agency of individual groups' responses - in terms of site occupation population crashes or population resilience - to inferred climate change. We have here chosen to employ a Bayesian approach because this is the only way from to work up from chronologies of change focusing on individual sites. In terms of individual human responses to local environmental change - the fundamental question of this paper - we suggest that this tacking from the small scale to the subcontinental provides the best basis for analysis of specific changes in occupation and resilience strategies of Mesolithic populations.

This paper investigates five different case study regions across northwest Europe - Belgium, northern France, Denmark, Ireland and Britain - to conduct a comparative analysis between different regions, in order to investigate whether there was a persistence, hiatus, or disappearance of site occupations around the $8.2 \mathrm{ka}$ $\mathrm{BP}$ event. As part of this we produce Bayesian statistical models for individual sites. Our approach looks at evidence for human presence from different sites across the region to engage with spatial and temporal patterns in Mesolithic human responses in north-west Atlantic Europe. This approach provides a baseline for further research on human responses to the $8.2 \mathrm{ka}$ BP event in their inter-regional and long-term 
contexts, as well as emphasising locations where human presence spans the $8.2 \mathrm{ka}$ $\mathrm{BP}$ event $_{1}$ as these will have key potential for analysis of palaeoenvironmental proxies.

\section{The nature of the $8.2 \mathrm{ka} B P$ event}

The $8.2 \mathrm{ka} \mathrm{BP}$ ( $8200 \mathrm{cal}$. BP) event is regarded as the largest abrupt climate change event of the Holocene period (Alley et al. 1997; Alley and Ágústsdóttir 2005). It was first identified in the Greenland ice cores (Alley et al. 1997; Rasmussen et al. 2007; Thomas et al. 2007), but has subsequently been reported in multiple proxies across Europe (Magny et al. 2003; Seppä et al. 2007; Prasad et al. 2009; Zillén and Snowball 2009; Daley et al. 2011; Giesecke et al. 2011), and throughout the Northern (Morrill and Jacobsen 2005; Shuman 2012; Liu et al. 2013; Dixit et al. 2014) and Southern Hemispheres (Morrill and Jacobsen 2005; Cheng et al. 2009; Bustamante et al. 2016). In the Northern Hemisphere the event has been cited as precipitating a cold period, with a drop in temperature for example of $6 \pm 2^{\circ} \mathrm{C}$ at Summit, Greenland (Alley et al. 1997) and of c. $1.6^{\circ} \mathrm{C}$ at Hawes Water, northwest England (Lang et al. 2010) that, according to counts of Greenland ice core layers, lasted a total of just over 160 years (Thomas et al. 2007). The event was reportedly caused by a glacier meltwater outburst from Laurentide lakes Agassiz and Ojibway around $8470 \mathrm{cal} \mathrm{BP}$, which reduced deep water formation and caused an abrupt slowdown of the Atlantic meridional overturning circulation (Barber et al. 1999). This hypothesis has been supported by work showing two sea-level jumps between 8.5 and $8.25 \mathrm{ka} \mathrm{BP}$ (Törnqvist and Hijma 2012). However, the causal attribution of meltwater outbursts to the $8.2 \mathrm{ka}$ BP signal in Greenland has recently been complicated by the identification of three separate outburst events (Jennings et al. 2015). In northwest Europe this three-step process has been recently confirmed from estuarine and salt-marsh deposits in southwest Scotland (Lawrence et al. 2016). This work identifies sea-level jumps at c. 8760-8640, 8595-8465, and 8330-8210 cal BP (Lawrence et al. 2016).

Alongside this recent problematisation of the nature and magnitude of the 8.2 ka BP event, there have been two different studies that have indicated the 'event' might be better conceived of in the context of much longer climate change processes. First, Alley and Ágústsdóttir (2005) highlighted contrasts between some palaeoclimate records that have indicated abrupt changes around $8.2 \mathrm{ka} \mathrm{BP}$, and other records that have suggested much longer periods of change. Second, work by Rohling and Pälike (2005) has noted how different records from around the globe indicate that the $8.2 \mathrm{ka} \mathrm{BP}$ event needs to be understood in the context of a longer period of change that spanned 400-600 years, and started around $8600 \mathrm{cal}$ BP. The issue of differential terrestrial ecosystem responses to the $8.2 \mathrm{ka} \mathrm{BP}$ event as originally recorded in Greenland has become an increasingly complex one, with considerations of differential responses based on proxy types (Seppä et al. 2007; Prasad et al. 2009; Zillén and Snowball 2009; Giesecke et al. 2011), geographical location (Seppä et al. 2007; Prasad et al. 2009), and various chronological discrepancies in proxy records (Torbenson et al. 2015). Furthermore, work by Magny et al. (2003) has suggested that there were different hydrological responses to the $8.2 \mathrm{ka}$ BP event in Europe based on latitude.

Considering all this work, it is reasonable to assume that there was

complexity in both the timing of ecosystem responses to the $8.2 \mathrm{ka} \mathrm{BP}$ event, and the regional magnitude of these responses. Indeed, lagged ecosystem responses would arguably have had a greater impact on Mesolithic foragers than declines in temperature in themselves. Recent work on other continents has suggested that there were up to 300 year lags in human responses to similar Holocene climate change events (Kelly et al. 2013). This emphasizes that in order to understand human resilience to the $8.2 \mathrm{ka}$ BP event, we must select sites for investigation within a broad time envelope around the event of interest, as well as in very high resolution 
palaeoclimate proxies. An added benefit of this broad event envelope approach is that enables us to question whether longer-term sea-level rises might have had a greater impact on Mesolithic societies, rather than an abrupt climate change event. As mentioned above, this approach will also enable us to locate key study areas for the investigation of palaeoenvironmental records. Only by identifying key regions with both detailed anthropogenic and palaeoenvironment sequences will we be able to overcome the inevitable problem of equifinality (cf. Robinson et al. 2013) between abrupt versus more gradual causal mechanisms.

\section{Method and Materials}

In order to assess the human evidence for responses to an $8.2 \mathrm{ka} \mathrm{BP}$ event, published data sets from the United Kingdom, Ireland, southern Scandinavia, northwestern France and Belgium were collated (Fig. 1; supplementary data). These case study areas were selected to sample a broad geographical area of northwest Atlantic Europe. Measurements were included in the analysis if they produced a calibrated range within the millennium centred on $8200 \mathrm{cal}$ BP ( $8700-7700 \mathrm{cal} \mathrm{BP})$ at $95 \%$ confidence (see supplementary data). This wide period was selected (see discussion above) in order that evidence for activity before and after the event might be identified; in order that long term evidence for change to be approached; in order that uncertainty in the timing of the $8.2 \mathrm{ka}$ BP event in Greenland might be accounted for; and in order that an 'event' that had a significant temporal duration would be wholly included in the analysis. Only data from 'anthropogenic' sites (rather than palaeoenvironmental sequences) were included, or in the case of one site, an estimate for human activity produced from two results on peat deposits superimposed above and below human activity (see model structure presented in supplementary data). Results had to be published with the laboratory code to be included.

Data were calibrated using using OxCal 4.2 (Bronk Ramsey 1995; 2009), and the internationally agreed calibration curve for the Northern Hemisphere (IntCal13; Reimer et al. 2013). In order to ensure that sites with multiple measurements were not over represented in the analysis - and therefore the specific histories of excavation and post-excavation research at individual sites do not bias our interpretations - a consistent approach was taken to the treatment of results. Radiocarbon results were presented as termini post quos if they were produced on samples that could have included inbuilt age offsets (undefined charcoal and shell samples). Results were presented as "outliers" if the nature of the dated samples are not identified in the source datasets. For some of the sites shown in Fig. 1, this means that not all the results from a site are presented in the analysis below (see supplementary data). Sites with more than four radiocarbon measurements were modelled using a simple "uniform phase model" in OxCal, and "Boundary" parameters for the start and end of activity used in the subsequent analysis (see supplementary data; Bronk Ramsey 2009). For sites with fewer results, an estimate for the "First" and "Last" dated events from the anthropogenic activity were included in the analysis (see supplementary data; Bronk Ramsey 2009). This approach produced no more than two distributions per site, ensuring that no site was overrepresented in the analysis, as well as attempting to deal with some of the statistical scatter associated with assemblages of radiocarbon data.

We believe this this first attempt at Bayesian site-specific methodology is unique in beginning to map spatial variation in responses to global climate change events, and to tack from human responses at individual sites to a sub-continental scale.

Figure 1. Sites with radiocarbon dates that were assessed from the 100 year time envelope for the $8.2 \mathrm{ka}$ BP event. Radiocarbon dates were selected which were produced on anthropogenic samples from this window. Results (Fig. 2) were only 
included in the analysis discussed below (Fig. 3 and 4) if they were produced on shortlife samples.

\section{Discussion}

We identified 89 sites with 265 radiocarbon measurements_which satisfied our methodological considerations from our case study areas. The posterior density estimates or calibrated radiocarbon distributions from sites with measurements on short-life samples associated with anthropogenic activity are shown in Fig. 2. Fig. 3 shows the results in the centuries either side of the $8.2 \mathrm{ka}$ BP event. From the available data it is apparent that human populations were present in the study area before and after $8200 \mathrm{cal} \mathrm{BP}$.

Figure 2. Distributions included in the analysis. Calibrated radiocarbon dates or posterior density estimates (see text and supplementary material Sheet 2) for details of samples and their treatment.

Figure 3. Maps showing probability distributions for the centuries either side of $8.2 \mathrm{ka}$ * $\mathrm{BP}$. The size of the points is proportional the to probability of human activity at the associated site. The represent the posterior density estimates shown in Figure 2 in map form; the larger the point the more probable that there is human activity at a site.

Visual inspection of these data suggests no significant difference between the estimates for human activity at the century level, or indeed in more detail in 50 year time slices (Fig. 4) around 8200 cal BP. As well as visually scrutinising distributions, it is possible to estimate the probability that activity at individual sites began before and after the $8.2 \mathrm{ka} \mathrm{BP}$ event, as it is identified in the GICC02 core in Greenland (8236 \pm 47 BP; Vinther et al. 2006; Rasmussen et al. 2006). The results of our analysis provide us with 83 shortlife posterior density estimates or calibrated

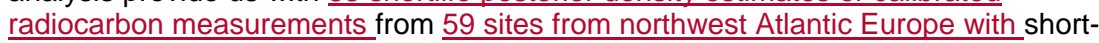
lived samples representing estimates for activity (where there is one results), or estimates for the earliest and latest activity (where there are more results) in the millennium focusing on the $8.2 \mathrm{ka} \mathrm{BP}$ event. It is more probable than not that 41 estimates for activity at these sites pre-date the $8.2 \mathrm{ka}$ BP event, and that 42 estimates for activity at these sites post-date the $8.2 \mathrm{ka} \mathrm{BP}$ event (see supplementary data). In short, there does not seem to be a significant difference for activity at sites either side of the $8.2 \mathrm{ka}$ BP event in northwest Atlantic Europe as a whole. From figures 2 and 3 it is not apparent that there is any spatial patterning in activity in human responses to the $8.2 \mathrm{ka} \mathrm{BP}$ event at the precision currently available to us.

Figure 4. Maps showing probability distributions for the in 50 year time slices either side of $8.2 \mathrm{ka} \mathrm{BP}$. The size of the points is proportional the to probability of human activity at the associated site. The represent the posterior density estimates shown in Figure 2 in map form; the larger the point the more probable that there is human activity at a site.

Across northwest Atlantic Europe as a whole human presence - indicated by activity at sites - does not demonstrate an initially dramatic and then gradual reduction following the $8.2 \mathrm{ka} \mathrm{BP}$ event. Evidence from individual sites in the study region has been used to suggest this trend in population levels (e.g. Wicks and Mithen 2014), but at a regional level this does not seem to be the case. Analysis at the regional level is essential in this case, as responses might well include changes in mobility strategies or occupation of other sites.

Formatted: Indent: First line: $0 \mathrm{~cm}$ 
Relating presence of activity on sites to population as a whole is a notoriously difficult process. Variables include history of research (in both excavation and postexcavation approaches), as well as the difficulties of using imprecise radiocarbon distributions. Beyond this consideration we believe that a seemingly stable number of sites in occupation across the region as a whole is indicative of a human population with at least some continuity in the organisation of residence density, and which indicates resilience to what has been suggested as the largest abrupt climate change of the Holocene period.

For most of the sites presented here there are no local palaeoenvironmental proxy records spanning the $8.2 \mathrm{ka} \mathrm{BP}$ 'event'. We therefore currently have very limited understanding of the local conditions pertinent to human populations. Clearly an important next step will be for targeted palaeoenvironmental work to identify areas with potential sequences in proximity to anthropogenic sites. These sequences would similarly be best if they were to span palaeoenvironmental conditions as much as possible either side of the $8.2 \mathrm{ka} \mathrm{BP}$ event. In this way it should be possible to use estimates for these site-specific palaeoenvironmental events and site-specific anthropogenic occupation to explore individual groups' responses to climate change. The search for such sequences will be difficult, but it is necessary, as we suggest that there is an even more important implication of the absence of local proxies in the majority of cases. When looking at individual sites and thinking about human responses, or looking at broad scale regional population estimates, we argue that there is a risk of correlating a chronologically imprecisely defined international event with the expectation of local palaeoenvironmental change and human responses. We suggest such narratives risk conflating or 'sucking in and smearing' (Baillie 1990) human cultural choices and attributing as causal mechanisms for these choices imprecisely defined palaeoclimate change events. This is especially relevant in cases where datasets are limited and chronologies poorly defined. When looking at individual sites without palaeoenvironmental proxies, or looking at a single regional population estimate there can be an assumption that environments responded uniformly and in the same way. Such an approach risks a very significant over simplification, and without robust chronologies for individual sites and local evidence for the effects of climate change we risk glossing any human activity in the mid 9th millennium BP as a response to the 8.2 ka BP 'event'.

This tendency for conflation of human social change with perceived environmental change has long been recognised. In 1998, Lowe and Higham wrote a short, insightful paper detailing how linkages between evidence from the palaeoenvironmental record could become "mythicized". Lowe and Higham (1998, 428) highlighted a tendency amongst researchers to produce age-based linkages between evidence, which "...may enter the literature as if proven fact because the limitations of the data are rarely communicated clearly, whether unwittingly or otherwise." Oldfield (2001, 123; cf. Blaauw 2012) has termed this approach to the interpretation of palaeoenvironmental chronological data as the creation of 'coherent myths'; coherent myths are created when the inherent uncertainty or noise in data is glossed over in order to create a directional causal narrative or driving relationship. As we have begun to demonstrate here in order to avoid such coherent myths we require site-specific, robust, probabilistic chronologies for human activities and climate change palaeoenvironmental events.

\section{Conclusions}

The evidence presented here from case studies across northwest Atlantic Europe does not demonstrate a catastrophic decline in the numbers of sites - and we suggest population - immediately after the $8.2 \mathrm{ka}$ BP event, or even in the centuries after this, as has been suggested from individual sites within specific regions (e.g. Wicks and Mithen 2014). Moreover, the data we have presented here 
suggest the continued persistence of a steady numbers of sites - and we suggest population - over 1000 years in northwest Atlantic Europe.

Undoubtedly natural events with cataclysmic impacts on human societies did - and do - occur, but in northwest Atlantic Europe the $8.2 \mathrm{ka} \mathrm{BP}$ event does not seem to have been one of these. We cannot assume that individual climate change events indicated at the global scale in non-human proxies necessarily has significant impacts on human populations at the local or sub-continental scale. Rather than simple linear population responses to individual climate change events, overall demographic trends might result from more combinations of more complex contributing factors. Increasingly in northwest Europe archaeologists are recognising that successful hunter-gatherer groups had - perhaps by their nature - developed societies with sophisticated environmental knowledge that responded to or mitigated against climate and social change (e.g. Griffiths 2014; Crombé et al. 2015). Resilience in hunter-gatherer societies is emphasised by numerous anthropological examples where exchange networks, mobility strategies, kin networks, and curated knowledge about surviving are socially important. If humans in this part of the world persisted as relatively stable populations after the $8.2 \mathrm{ka}$ BP event it was probably because their cultural adaptations allowed them to persist (cf. Crombé and Robinson 2017).

Without investigating more regional and local palaeoenvironmental records, it will be impossible to investigate the specific relationships and complexities in these different adaptive strategies and different kinds of palaeoecological change. Without a critical approach to the chronological evidence, there is a danger that events such as the 8.2 ka BP event are marshalled as chronological 'moveable feasts' or mythic events, ones that are deployed as causal factors in narratives for when evidence is poorly defined in the archaeological record.

\section{Acknowledgements}

Marc Vander Linden and Kevan Edinborogh provided data and useful feedback for this paper. Additional data collection was undertaken using the EUROEVOL dataset available from http://discovery.ucl.ac.uk/1469811/ Manning, K., Timpson, A.,

Colledge, S., Crema, E., Shennan, S. 2015. The cultural evolution of Neolithic Europe. EUROEVOL Dataset. Any mistakes are our own.

Travel to attend project meetings for this research was supported by the International Union for Quaternary Research (INQUA) HABCOM International Focus Group for early careers researchers. Project 1404.

\section{References}

Alley, R.B., Ágústsdóttir, A.M., 2005. The 8k event: cause and consequences of a major Holocene abrupt climate change. Quaternary Science Reviews 24, 1123-1149.

Alley, R.B., Mayewski, P.A., Sowers, T., Stuiver, M., Taylor, K.C., Clark, P.U., 1997. Holocene climate instability: a prominent, widespread event $8200 \mathrm{yr}$ ago. Geology 25, 483-486.

Baillie, M., 1991. Suck-in and smear. Two related chronological problems for the 90s. J. of Theortical Arch 2, 12-16.

Barber, D.C., Dyke, A., Hillaire-Marcel, C., Jennings, A.E., Andrews, J.T., Kerwin, M.W., Bilodeau, G., McNeely, R., Southon, J., Morehead, M.D., Gagnon, J.M., 1999. Forcing of the cold event $8200 \mathrm{yr}$ ago by catastrophic drainage of laurentide lakes. Nature 400, 344-348. 
Blaauw, M., 2012. Out of tune: the dangers of aligning proxy archives. Quaternary Science Reviews 36, 38-49.

Bronk Ramsey, C. 1995. Radiocarbon calibration and analysis of stratigraphy: the OxCal program. Radiocarbon 37, 2, 425-30.

Bronk Ramsey, C., 2009. Bayesian analysis of radiocarbon dates. Radiocarbon 51 337-60.

Bustamante, M.G., Cruz, F.W., Vuille, M., Apaéstegui, J., Strikis, N., Panizo, G. Novello, F.V., Deininger, M., Sifeddine, A., Cheng, H., Moquet, J.S., Guyot, J.L., Santos, R.V., Segura, H., Edwards, R.L., 2016. Holocene changes in monsoon precipitation in the Andes of NE Peru based on $\delta 180$ speleothem records. Quaternary Science Reviews 146, 274-287.

Cheng, H., Fleitmann, D., Edwards, R.L., Wang, X., Cruz, F.W., Auler, A.S., Mangini, A., Wang, Y., Kong, X., Kong, X., Burns, S.J., Matter, A., 2009. Timing and structure of the $8.2 \mathrm{kyr}$ B.P. event inferred from $\delta 180$ records of stalagmites from China, Oman, and Brazil. Geology 37(11), 1007-1010.

Crema, E., Habu, J., Kobayashi, K., Madella, M., 2016. Summed Probability Distribution of 14C Dates Suggests Regional Divergences in the Population Dynamics of the Jomon Period in Eastern Japan. PLoS One 11(4) 10.1371/journal.pone.0154809

Crombé, P., Robinson, E., 2017. Human resilience to Lateglacial climate and environmental change in the Scheldt basin (NW Belgium). Quaternary International 428(B), 50-63.

Crombé, P., Verhegge, J., Deforce, K., Meylemans, E., Robinson, E., 2015. Wetland landscape dynamics, Swifterbant land use systems, and the Mesolithic-Neolithic transition in the southern North Sea basin. Quaternary International 378, 119-133.

Daley, T.J., Thomas, E.R., Holmes, J.A., Street-Perrott, F.A., Chapman, M.R., Tindall, J.C., Valdes, P.J., Loader, N.J., Marshall, J.D., Wolff, E.W., Hopley, P.J., Atkinson, T., Barber, K.E., Fisher, E.H., Robertson, I., Hughes, P.D.M., Roberts, C.N., 2011. The 8200 yr BP cold event in stable isotope records from the North Atlantic region. Global and Planetary Change 79, 288-302.

Dixit, Y., Hodell, D.A., Sinha, R., Petrie, C.A., 2014. Abrupt weakening of the Indian summer monsoon at $8.2 \mathrm{kyr}$ B.P. Earth and Planetary Science Letters 391, 16-23.

Giesecke, T., Bennett, K.D., Birks, H.J.B., Bjune, A.E., Bozilova, E., Feurdean, A., Finsinger, W., Froyd, C., Pokorný, P., Rösch, M., Seppä, H., Tonkov, S., Valsecchi, V., Wolters, S., 2011. The pace of Holocene climate change-testing for synchronous developments. Quaternary Science Reviews 30, 2805-2814.

Griffiths, S. 2014. Points in time. The mesolithic-neolithic transition and the chronology of late rod microliths in Britain. Oxford Journal of Archaeology, 33, 3 , $\underline{221-43}$.

Jennings, A., Andrews, J., Pearce, C., Wilson, L., Ólfasdóttir, S., 2015. Detrital carbonate peaks on the Labrador shelf, a 13-7 ka template for freshwater forcing from the Hudson Strait outlet of the Laurentide Ice Sheet into the subpolar gyre. Quaternary Science Reviews 107, 62-80. 
Kelly, R.L., Surovell, T.A., Shuman, B.N., Smith, G.M., 2013. A continuous climatic impact on Holocene human populations in the Rocky Mountains. Proceedings of the National Academy of Science 110(2), 443-447.

Lang, B., Bedford, A., Brooks, S.J., Jones, R.T., Richardson, N., Birks, H.J.B., Marshall, J.D., 2010. Early-Holocene temperature variability inferred from chironomid assemblages at Hawes Water, northwest England. The Holocene 20(6), 943-954.

Lawrence, T., Long, A.J., Gehrels, W.R., Jackson, L.P., Smith, D.E., 2016. Relative sea-level data from southwest Scotland constrain meltwater-driven sea-level jumps prior to the 8.2 kyr BP event. Quaternary Science Reviews 151, 292-308.

Lowe, D. and Higham, T. 1998. Hit-or-myth? Linking a 1259 AD acid spike with an Okataina eruption. Antiquity 72, 427-31

Liu, Y-H., Henderson, G.M., Hu, C-Y., Mason, A.J., Charnley, N., Johnson, K.R., Xie, S-C., 2013. Links between the East Asian monsoon and North Atlantic climate during the 8,200 year event. Nature Geoscience 6,117-120.

Magny, M., Bégeot, C., Guiot, J., Peyron, O., 2003. Contrasting patterns of hydrological changes in Europe in response to Holocene climate cooling phases. Quaternary Science Reviews 22, 1589-1596.

Manninen, M., 2014. Culture, Behaviour, and the 8200 cal BP Cold Event: Organisational Change and Culture Environment Dynamics in Late Mesolithic Northern Fennoscandia. Helsinki: The Archaeological Society of Finland.

Morrill, C., Jacobsen, R.M., 2005. How widespread were climate anomalies 8200 years ago? Geophysical Research Letters 32, L19701.

Oldfield, F., 2001. A question of timing: a comment on Hong, Jiang, Lui, Zhou, Beer, Li, Leng, Hong and Qin. Holocene 11, 123-124.

Prasad, S., Witt, A., Kienel, U., Dulski, P., Bauer, E., Yancheva, G., 2009. The 8.2 ka event: evidence for seasonal differences and the rate of climate change in western Europe. Global and Planetary Change 67, 218-226.

Rasmussen, S.O., Vinther, B.M., Clausen, H.B., Andersen, K.K., 2007. Early Holocene climate oscillations recorded in three Greenland ice cores. Quaternary Science Reviews 26, 1907-1914.

Reimer, P., Bard, E., Bayliss, A., Beck, J., Blackwell, P., Bronk Ramsey, C., Grootes, P., Guilderson, T., Haflidason, H., Hajdas, I., Hatté, C., Heaton, T., Hoffmann, D., Hogg, A., Hughen, K., Kaiser, K., Kromer, B., Manning, S., Niu, M., Reimer, R., Richards, D., Scott, E., Southon, J., Staff, R., Turney, C., van der Plicht, J., 2013. IntCal13 and Marine13 Radiocarbon Age Calibration Curves 0-50,000 Years cal BP. Radiocarbon 55, 1869-1887.

Riede, F., 2009. Climate and demography in early prehistory: using calibrated 14C dates as population proxies. Hum. Biol. 81, 309-337.

Robinson, E., Van Strydonck, M., Gelorini, V., Crombé, P., 2013. Radiocarbon chronology and the correlation of hunter-gatherer sociocultural change with abrupt 
palaeoclimate change: the Middle Mesolithic in the Rhine-Meuse-Scheldt area of northwest Europe. J. Arch. Sci. 40, 755-763.

Rohling, E.J., Pälike, H., 2005. Centennial-scale climate cooling with a sudden cold event around 8,200 years ago.

Seppä, H., Birks, H.J.B., Giesecke, T., Hammarlund, D., Alenius, T., Antonsson, K., Bjune, A.E., Heikkilä, M., MacDonald, G.M., Ojala, A.E.K., Telford, R.J., Veski, S., 2007. Spatial structure of the $8200 \mathrm{cal}$ yr BP event in northern Europe. Clim. Past. 3, 225-236.

Shennan, S, Downey, S., Timpson, A., Edinborough, K., Colledge, S., Kerig. T., Manning, K., Thomas, M., 2013. Regional population collapse followed initial agriculture booms in mid-Holocene Europe. Nat. Comms. 4, article number: 2486 doi:10.1038/ncomms3486

Shuman, B. 2012. Patterns, processes, and impacts of abrupt climate change in a warm world: the past 11,700 years. WIREs Climate Change $3,19-43$.

Thomas, E.R., Wolff, E.W., Mulvaney, R., Steffensen, J.P., Johnsen, S.J., Arrowsmith, C., White, J.W.C., Vaughn, B., Popp, T., 2007. The 8.2 ka event from Greenland ice cores. Quaternary Science Reviews 26, 70-81.

Törnqvist, T.E., Hijma, M.P., 2012. Links between early Holocene ice-sheet decay, sea-level rise and abrupt climate change. Nature Geoscience 5, 601-606.

Torbenson, M.C.A., Plunkett, G., Brown, D.M., Pilcher, J.R., Leuschner, H.H., 2015. Asynchrony in key Holocene chronologies: evidence from Irish bog pines. Geology 43(9), 799-802.

Vinther, B. M. and Clausen, H. B. and Johnsen, S. J. and Rasmussen, S. O. and Andersen, K. K. and Buchardt, S. L. and Dahl-Jensen, D. and Seierstad, I. K. and Siggaard-Andersen, M.-L. and Steffensen, J. P. and Svensson, A. and Olsen, J. and Heinemeier, J., 2006. A synchronized dating of three Greenland ice cores throughout the Holocene. J. Geophys. Res., 111 (D13) http://dx.doi.org/10.1029/2005JD006921

Wicks, K., Mithen, S., 2014. The impact of the abrupt 8.2 ka cold event on the Mesolithic population of western Scotland: a Bayesian chronological analysis using 'activity events' as a population proxy. J. Arch. Sci. 45, 240-269.

Zillén, L., Snowball, I., 2009. Complexity of the 8 ka climate event in Sweden recorded by varved lake sediments. Boreas $38,493-503$.

\section{Figures}

Figure 1. Location map of the sites included in the analysis. Site numbers can be compared to the UID on the first page of the supplementary material database.

Figure 2. Distributions included in the analysis. Calibrated radiocarbon dates or posterior density estimates (see text and supplementary material $\underline{\text { Sheet }} \underline{2}$ ) for details of samples and their treatment.

Figure 3. Maps showing probability distributions for the centuries either side of $8.2 \mathrm{ka}$ $\mathrm{BP}$. The size of the points is proportional the to probability of human activity at the 
associated site. The represent the posterior density estimates shown in Fig. 2 in map form; the larger the point the more probable that there is human activity at a site.

Figure 4. Maps showing probability distributions for the in 50 year time slices either side of $8.2 \mathrm{ka} \mathrm{BP}$. The size of the points is proportional the to probability of human activity at the associated site. The represent the posterior density estimates shown in Fig. 2 in map form; the larger the point the more probable that there is human activity at a site.

\section{Supplementary data}

Sheet 1 ; supplementary data information

Sheet 2; site UID, name and location.

Sheet $\underline{3}$; sample number and treatment in model based on sampled material.

Sheet 4 ; sample modelling.

Sheet 5; modelling approach to estimate parameters occurring before the $8.2 \mathrm{ka} \mathrm{BP}$ event as estimated in GICC02. Users would have to run the model shown on sheet 4 and save the output files in order to calculate this model.

Sheet 6; probabilities that each shortlife parameter shown in the Sheet 4 model occurred before the $8.2 \mathrm{ka}$ BP event.

Sheet 7; modelling approach to estimate parameters occurring after the $8.2 \mathrm{ka} \mathrm{BP}$ event as estimated in GICC02. Users would have to run the model shown on sheet 4 and save the output files in order to calculate this model.

Sheet 8; probabilities that each shortlife parameter shown in the Sheet 4 model occurred after the $8.2 \mathrm{ka}$ BP event. 